\title{
Tell me what you see: Late deposition of an atypical metallic artefact in Perdigões
}

\author{
Ana Catarina Basílio (ICArEHB-Ualg) \\ António Carlos Valera (NIA, ERA Arqueologia; ICArEHB-Ualg)
}

\begin{abstract}
This work presents the deposition of a deformed metallic piece in the re-cutting of Ditch 7 in the Complex of Ditched enclosures of Perdigões. The filling of this reopening was done with the accumulation of a great set of stones, on top of which this elongated and serrated metal element of atypical typology was identified.

This piece, due to the absence of direct parallels in the national territory, allows to discuss not only typological and terminological questions, in face of its formal distance from the Palmela Points/arrowheads or the tanged daggers. At the same time allows to think about its biography (presence of a serrated edge and distortion), contextual and chronological insertion, being noted a recurrence of certain types of late depositions in Perdigões, as is the case of this re-cutting in Ditch 7, dated from the third quarter of the 3rd millennium BC.
\end{abstract}

\section{Resumo (Tell me what you see: Deposição tardia de um artefacto metálico atípico nos Perdigões)}

Com o presente trabalho pretende-se apresentar a deposição de uma peça metálica deformada no Complexo de Recintos dos Perdigões, mais concretamente no re-cutting do Fosso 7. O enchimento desta reabertura foi feito com a acumulação de um grande conjunto de pedras, no topo das quais foi identificado este elemento metálico alongado e serrilhado, de tipologia atípica.

Esta peça, pela ausência de paralelos directos em território nacional, permite discutir não só questões tipológicas e terminológicas, pelo seu afastamento formal em relação às Pontas Palmela ou aos Punhais de Lingueta, como também pensar sobre a sua biografia (presença de um bordo serrilhado), inserção contextual e cronológica, verificando-se uma recorrência de determinados tipos de deposições tardias nos Perdigões, como acontece neste re-cutting do terceiro quartel do 3o milénio a.C.

\section{Introduction}

Archaeologists need to organise and categorise the archaeological reality, mainly in order to make this reality capable of study. As such, one of the most immediate archaeological processes corresponds to the typological classification - what to call things. However, when an artefact, a context or even a site, flees the known "standards", the exercise of classification is hampered.

This is the case of the understudy metallic element recovered in the Complex of Ditched Enclosures of Perdigões. Due to its elongated shape, serrated edge and flattened tang it does not present a clear connection to the Chalcolithic "weaponry", in which one can include the Jabalinas and Palmela points/arrowheads and the daggers. This scenario, and the apparently extended biography of the artefact allowed one to question both the meaning and agency that this element 
might have had in the prehistoric groups, suggesting a social function that might have been connected to the physical record of memories, cycles and time. (Fig. 1)

Adding to the lack of direct parallels, the physical state of the metallic artefact and even the deposition suggest that this element might not only be atypical in what concerns its morphology. Is noteworthy that it is one of the only metallic artefacts deposited in a ditch, at least in Perdigões, working as an integrant part of the filling of a second recutting moment of Ditch 7. This moment in the biography of the mentioned structure presents a terminus post quem date from the last quarter of the 3rd millennium BC, which might explain several of the unusual characteristics of the artefact, considering the ongoing social phenomenon's occurring in SW Iberia (Valera In press; 2015a). Still, the presence of post-depositional processes - namely a deep plough - might also influence the contexts in which the blade was recovered.

Nevertheless, those characteristics must be further discussed, to bring one closer to the biography, meanings and functions of the blade deposited on top of ditch 7 in Perdigões.

\section{Archaeological framing}

The Ditched Enclosure Complex of Perdigões it is located in Reguengos de Monsaraz, $35 \mathrm{~km}$ from Évora (South of Portugal - Alentejo), at the western extreme of the Álamo river valley - with a Latitude of 38.441789 a and a Longitude of -7.545106 - in a natural amphitheatre surrounded by lightweight strands, which restricts the site's visibility to the valley that develops to the east (Lago et al. 1998).

Due to its 20 years of investigation, is one of the most known sites of the peninsular prehistory (Lago et al. 1998; Valera 2008; Valera et al. 2014b; Valera 2015a; Valera \& Basílio 2017; Valera \& Evangelista 2014; Valera \& Godinho 2009; 2010; Valera 2018), presenting a great diversity of practices during its 1500 years of occupation, with a particular overlap and intensity in the central enclosures (Valera et al. 2014b). (Fig.2)

In the course of its history, the existence of astronomical relations and a tendency towards circularity and concentricity, emphasises the correspondence and continuity between the ideological and cosmological system of the groups that came together in Perdigões. This correspondence is also visible in the funerary structures and the maintenance of a regular deposition of human remains (Evangelista \& Valera 2019; Valera et al. 2014a; Valera \& Godinho 2009; 2010).

This behaviour is also detected in the later moments of this site life, in the transition between the 3rd and 2nd millennia BC (Valera \& Basílio 2017), a phase that still needs to be better characterised and, as such, understood. Nevertheless, in the most recent interventions in Perdigões, several contexts with evidence of activities dated from this specific phase were identified, being this the case of Ditch 7 .

The biography of this structure is mostly composed by different moments of filling, depositions and re-cuttings, corresponding to an extremely complex and dynamic ditch. Its intervention began in 2013, in order to understand and clarify the relationship between this structure and 
Ditch 8 that, according to the geophysical data, were superimposed on the intervened area (Valera 2013).

During the three years of excavation it was thus possible to verify that Ditch 7 had a "V" section, with $3.90 \mathrm{~m}$ of maximum width on the mouth, $0.30 \mathrm{~m}$ of diameter at the base and a maximum depth of 2,95m, making it one of the most substantial ditches identified and excavated, so far, in Perdigões (Valera 2015b).

It presents two different phases. The first one corresponds to the deposition of generally horizontalized layers that fill the ditch almost up to its top, with the inclusion of some stone elements spread through the stratigraphy. Nevertheless, the lower third of the ditch must be stressed. At an initial stage in the filling of Ditch 7, one identified successive, intercalated and arranged depositions of rocks, ceramics sherds and faunal elements, as previously noted in the sections excavated in both Ditch 3 and 4, but also in almost every intervened archaeological contexts in Perdigões, being this trinomial a constant repetition in this enclosure (Valera 2015a; 2014). (Fig. 3)

Yet, and matching the depositional behaviour of the remaining excavated ditch sections, in two continuous horizontal layers in the bottom of Ditch 7 - namely [91] and [92] - human remains, a jaw and skull fragments of a young individual $(\mathrm{MNI}=1)$ with an age around $>2 / 4$ year, were included as an integrant part of the deposition while associated to pottery sherds and faunal elements (Evangelista \& Valera 2019).

A second phase in the life of Ditch 7 corresponds to two moments of partial reopening of the structure. A first re-cutting - [80] - is excavated in the fillings of this ditch, having two depositional moments that create an agglomeration of large and medium rocks. Both deposits are then cut by a new re-cutting - [56] - being this second cut filled again by an irregular deposition of stones that, in the section excavated, are concentrated in the west wall of the ditch, presenting an unequal planimetry in the remaining identified area (Valera 2015b). In this second re-cutting, the density of archaeological materials is hugely reduced. Nevertheless, one of the first and foremost elements attributed to this final filling phase of Ditch 7, corresponds to the metallic object here understudy that it was deposited alone, in the middle of the rocks that filled the top of this reopening.

Even though the main features and material characteristics of this structure point to a Chalcolithic chronology $-3^{\text {rd }}$ millennium $\mathrm{BC}$ - only three radiocarbon date are available to Ditch 7 (Valera \& Basilio 2017). These allow specifying that the beginning of the filling of this ditch occurred during the second half of the $3^{\text {rd }}$ millennium BC, placing it in one of the chronological spans in which there is more activity within Perdigões (Valera et al. 2014b; Valera \& Basílio 2017). As such, Ditch 7 is contemporaneous with the second phase of Tomb 2, of the deposition of cremated human remains in the centre of the enclosure, with both ditches 1 and 2 (the two most exterior Chalcolithic ditches) and with Hut 2, again in the central area of Perdigões (Valera et al. 2014b; Valera \& Basílio 2017). (Fig. 4)

As its filling progresses, this structure also advances at a temporal level, presenting a date from the middle of the ditch (S.U. [86]), that can be traced to the middle of the 3rd quarter of the 3rd millennium BC, still in what was considered as the first phase of filling. This harmonious 
chronological trend is then interrupted by the chronology obtained for the first re-cutting moment (S.U. [63]). Contrary to what was expected, this phase presented a slightly older chronological span (2468-2291 BC) which can be justified by the existence of mixing processes that are associated with the re-excavation, reactivation and reformulation that Ditch 7 went through (Valera \& Basílio 2017).

As such, and considering that the chronological set of Ditch 7 is still being built, the terminus post quem used as a reference for the second reopening moment and, therefore, for the metallic artefact deposited on top of the ditch, is around the middle of the $3^{\text {rd }}$ quarter of the $3^{\text {rd }}$ millennium $\mathrm{BC}$ or even at the beginning of the last quarter of the same millennium. This period would match both the re-cutting and the deposition of the metallic element to the still blurry later phase of the life and practices of Perdigões enclosures. Adding to that, coexistence between the ditch context and components integrable into the "Bell Beaker phenomenon" is also noted, namely with a Vperforated ivory button (Valera et al. 2015; Valera \& Basílio 2017), being also highlightable the coexistence with several other metallic elements (Basílio \& Cabaço 2019). (Fig. 5)

\section{Deposition of the artefact: questions and problems}

The presence of metallic artefacts in the Ditched Enclosure Complex of Perdigões is not surprising, being this type of elements widely known through the enclosure's Chalcolithic contexts (Bottaini et al. 2018; Soares et al. 2014; Valera \&Basílio, 2017). This is also the scenario found in other regional sites, such as São Pedro (Valério et al. 2017), São Brás (Valério et al. 2019), Porto das Carretas (Soares 2011), and so on. However, the reduced numerical expression and representativeness of these artefacts, correspondingly decreases the morphological variability, existing a clear predominance of awls, foundry remnants and even ores. In opposition, there is a residual presence of artefacts usually known as "weapons", such as daggers, points/arrowheads, blades, having a diversified incidence within the second half of the $3^{\text {rd }}$ millennium BC, as observable, for example, in the distribution of Bell Beaker Palmela points/arrowheads (Kaiser 2003).

Yet, besides the general monotony drawn by the repeated morphology of these elements, some artefacts do not strictly fit in the Chalcolithic metallic typologies, presenting divergencies that hamper the classification process but also the comprehension of possible functionalities and meanings of this elements.

This is mainly visible in artefacts from the second half of the $3^{\text {rd }}$ millennium $B C$, but particularly in the ones used and possibly produced during the transition between the $3^{\text {rd }}$ and $2^{\text {nd }}$ millennia BC. In this period, in SW Iberia, a generalised shift and transitional climate was felt, being those same changes somehow connected, by most researchers, to several climatic events, usually grouped under the name " 4.2 ka climatic event" (Blanco-González et al. 2018). However, there are other disruptions in the ongoing social systems that originated different social answers that can be noted in variations in the material culture and in the general invisibility of architectures, settlements and practices in the SW region during the beginning of the Bronze Age (Basilio \& Cabaço 2019; Basílio 2018; Valera 2015a; In press; Valera \& Basílio, 2017). Also, changes in an ideology more linked to the "community" in the Neolithic and Chalcolithic are detectable in a progressive valorisation of the individual and of the integrity of the body (Valera 2015a; In press). 
This panorama can be related to the appearance of some divergent elements in the material culture, such as the metallic artefact recovered on top of Ditch 7 from Perdigões or even the spatula identified in the settlement of São Pedro (Valério et al. 2017). These "outliers" could act and be an integrant part of specific social practices, which would increase their value and enrich their biographies (Appadurai 1986).

Therefore, the piece here understudy allows to raise several questions that are not only related to its typology and undetermined designation (is it a blade, point, dagger or saw?), but also, with the composition, functionality and biography of the artefact, in which its depositions is included, in a critical moment in which the Chalcolithic way of life was ending.

\subsection{Typology}

Studying the material component of an archaeological site such as Perdigões requires an interpretation process that is dependent, on one side (of what is known for the site, either its chronology, material expressions, architectures and phasing), and on the other, of an analytical procedure of selection and organisation of the archaeological reality, whose creation is dependent on the researcher's interpretation and sense of the object. In turn, and acknowledging the subjectivity that is inherent to humans, the classification and typological processes are also dependent on this same sense, with a tendency to originate generalisations and even to question the existence - in an abstract manner - of the object itself (Vignaux 2000).

The development of these material typologies have been understood as representation and a way of getting closer to the communities associated to them, acting as "mirrors" that reflect as well as generate the sociocultural context of their use and production (Shanks \& Tilley 1987). As such, artefacts that present atypical morphologies, such as the one from Ditch 7, have a particularly troublesome analysis, mainly associated with the lack of suitable contextual and physical parallels.

The under-study metallic artefact has a strangely elongated shape, with a total length of $25 \mathrm{~cm}$, of which seven correspond to the tang (or peduncle). However, several common characteristics shared with the contemporary counterparts can be underlined, mainly in what concerns its generic morphological composition, with a clear distinction between the blade and the tang. This distinctive element can equally be noted in both the regional Jabalinas and the beaker Palmela points/arrowheads, but also the tonged daggers (punhais de lingueta in Portuguese). Nevertheless, the artefact from Ditch 7 also presents divergences which distance it from the mentioned elements.

Firstly, Perdigões artefact does not have a tang with a pointed tip. Instead, it presents a flattened termination, similar to the ones that can be found in the regional chisels. This might imply different processes for attaching the handles, reflecting a technological divergence, and, simultaneously, distinct utilisation strategies that can even reflect a double usage of both the blade and the edge of the tang, either in simultaneous or individually.

Secondly, the length of the blade. This element hinders the terminological attribution since it lacks some of the morphological characteristics needed to be considered a Palmela point (with a 
leaf type blade) or a dagger, not fitting exhaustively in any of the contemporaneous metallic typologies, whether at a regional or national scale. (Fig. 6)

As a result of this maladjustment, an analysis was carried out, relating both the length of the blade and of the tang from the main metallic elements present in SW Iberia, in the second half of the $3^{\text {rd }}$ millennium BC, namely the already highlighted Palmela points/arrowheads (228 exemplars measured), daggers (67 elements) and Jabalina points/arrowheads (34 artefacts). Even so, this exercise was not intended to be fully exhaustive, nor to collect the measurements of all the morphologically similar Iberian metal artefacts, but mainly to reflect the general tendency and behaviour of those same artefactual categories, recognising that there is much diversity in each of the used morphologies.

In total, 330 elements were studied, forming two cohesive clusters - one composed by the Palmela points/arrowheads, that mainly present tangs between $20-60 \mathrm{~mm}$ and blades with 40 $80 \mathrm{~mm}$, and the second one by the Jabalinas that, due its distinct typology, have tangs (180-240 $\mathrm{mm}$ ) longer than the blades $(40-60 \mathrm{~mm})$, creating an evidently separated concentration. The dagger group's elements are mainly spread in the measurement chart, presenting blades that fluctuate between 40-280 $\mathrm{mm}$ and tangs that can reach $60 \mathrm{~mm}$, being this typology the one that does not seem to have generally standardised dimensions. However, and even considering all this morphological variability, the Perdigões element moves away from all the groups, with $179 \mathrm{~mm}$ of blade and $71 \mathrm{~mm}$ of tang.

Still, the classification process implies a compartmentalisation and designation of the archaeological reality that, in the specific case of the artefact from Ditch 7, seems to be more closely connected to the daggers, even if not strictly fitting this group. As a result, one must understand the "dagger" from Perdigões as an element in "mutation" or "transition" between the more elongated Palmela points/arrowheads (because of the tang dimension), as it occurs in Humanejos (Blasco et al. 2011) or Torre do Ervedal 4 (Andrade 2016), and the daggers, due to the size of the blade (Comendador Rey 1998). Moreover, this "dagger" might not be the only one in an "intermediate stage" at the end of the Chalcolithic being known, for example, the spatula of São Pedro, with an equally abnormal typology (Valério et al. 2017).

\subsection{Composition}

One of the most researched questions concerning ancient metallurgy is related to the technological transition between the work of purer copper and what is known as arsenical copper. This change can be interpreted, in an embryonic stage, as an unintentional addition. However, the improvement of the mechanical characteristics of the metallic artefacts would be noted, and possibly appreciated and demanded, by the prehistoric users. Some of these enhancements are particularly notorious, evolving a shift in colour of the elements, making them more reddish (Orestes Vidigal et al. 2016). Adding to that, the upgrade in the artefact's hardness, the mitigation of casting defects and the reduction of the melting temperature would also be depicted (Orestes Vidigal et al. 2016).

The chronological factor is also considered, once it seems to be a gradual increase in the usage of arsenical copper in the casting of metallic artefacts, that is particularly notorious from the Iberian SW Middle Bronze Age onwards (Orestes Vidigal et al. 2016; Valério et al. 2016b). As such, 
it could also shed some light and help to clarify and rectify, not only the chronology of this artefact, but also justify its atypical morphology.

The artefact from Ditch 7 of Perdigões presents an almost pure chemical composition, being produced of $98,9 \%$ of copper (Bottaini et al. 2018). This composition is relatively common in Perdigões, at least in what concerns the analysed artefacts (Bottaini et al. 2018; Caro et al. 2015). Of the total of 331 metallic elements recovered so far in this archaeological site - 285 fragments, 25 awls and chisels and 21 daggers, points/arrowheads, blades and axes - only 27 artefacts were analysed. Of those merely $21 \%$ have a composition compatible with arsenical copper (Bottaini et al. 2018; Soares et al. 2014), at least if one considers the references used in other regionally and chronologically compatible studies, in which arsenic must have a presence equal or bigger than $2 \%$ in the composition to be considered as an element of the alloy (Orestes Vidigal et al. 2016; Valério et al. 2017; 2016b).

However, when one compares the tendency to a significant relevance of copper elements drawn by Perdigões metallic artefacts, to the behaviour of the elements from other archaeological sites in the southwest of the peninsula, a dichotomy pops up. In this region, there is a progressive increase in the inclusion (intentional or not) of arsenic in the composition of metal tools during the course of the Chalcolithic, that exponentially grows in the Bell Beaker phase, being well established in the Middle Bronze Age - reaching 90\% of the analysed elements (Bottaini et al. 2018; Orestes Vidigal et al. 2016; Valério et al. 2016b).

As such, the assemblage from Perdigões presents characteristics that can be linked to an essentially Chalcolithic tradition that coexists with decorated Bell Beakers without causing changes in the metallurgical production. In Perdigões it is still necessary to increase the analytical set, either in what concerns contexts or metallic tools dated from the transition between the $3^{\text {rd }}$ and $2^{\text {nd }}$ millennia BC. (Fig. 7)

It must also be emphasised that when one individually looks at the composition of the 27 analysed elements from Perdigões, and according to three artefactual categories - 1. Awls; 2. fragments and foundry remnants; 3 . Points/arrowheads, blades and daggers - the eight elements from the $3^{\text {rd }}$ group, in which the "dagger" from Ditch 7 is included, present a decrease in the utilisation of arsenical copper. This behaviour, that contradicts the fact that most of the daggers from the second half of the $3^{\text {rd }}$ millennium $B C$ in the region seem to be preferentially produced with arsenical copper as a reflection of an intentional choice (Orestes Vidigal et al. 2016), can be related to the size of the analysed sample in Perdigões. Still, in the fragments and foundry remnants, that are only represented by seven artefacts, there is a maintenance in the inclusion of arsenic. Nevertheless, and recognising that this panorama may undergo through changes with the increase of the analytical information and maybe getting closer to the regional values depicted in the daggers, the identified tendency may be indicative of a selection of raw materials in association to specific artefactual typologies - in the case of the understudy "dagger", with an atypical shape.

\subsection{Biography and deposition}

The terminological, typological and technological problems raised concerning the dagger from Ditch 7 of Perdigões can also be connected to the fact that this artefact has a more complex 
biography than the "simple" production-usage-discard cycle (Jârlea 2008). It was intentionally amortised due to the type of deposition, on top of the ditch, possibly having a double or even triple functionality throughout its life.

Firstly, it is noteworthy that this "dagger" was not recycled which would be a natural step in the life cycle of a metallic artefact, serving, after being remelted, as raw material to the production of other tools. Instead, it was physically modified and reformulated, which emphasises that this element would not have been specifically made to be deposited on top of Ditch 7 .

The reformulation that enriched the dagger's biography is materialised in the presence of a serrated edge, with a minimum number of 20 incisions, in on side the blade of the dagger. This element could give new functionality to the Perdigões's element, bringing it closer, although with a quite irregular edge, to the Chalcolithic "saws". On the other hand, and taking in consideration that this element was recovered at a site that shows uncountable ritualized social practices (Basílio \& Cabaço 2019; Evangelista \& Valera 2019; Valera, 2015a; 2008; Valera et al. 2014a; Valera \& Basílio 2017; Valera 2019), it can also have other meanings, namely the possible function as a "timer" and as an "artificial/external memory".

The perception of time and the need to measure it is essential to the prehistoric groups and to their way of live (either Palaeolithic, Chalcolithic or from the Bronze Age), since several of their activities - hunting, migration, reproduction, clothing, social practices, meetings and so on could be related to cyclic natural events. Those types of happenings, where the passage of time is more easily perceived, correspond to the synodic lunar years (phases/cycles) and the change between the different seasons (d'Errico et al. 2017; De Smedt \& De Cruz 2011). This knowledge and recognition allowed them to develop an "episodic memory" - the ability to remember, mentally travel and re-experience a past event - that it is then complemented by an "episodic future thinking" - the ability to project the future, simulating and predicting scenarios - being this related, and conditioned, by a cyclic notion of life (Atance \& O’Neill 2001; De Smedt \& De Cruz 2011; Tulving 2002).

As such, devices that serve as physical markers, and the related systems, can be traced in European borders at least since the Upper Palaeolithic (d'Errico et al. 2017). In this ancient chronology, they are usually associated with nonverbal symbolic mechanisms to communicate numerical information. However, these artificial memory systems also allow these human groups to process, storage and transmit a message (or messages) using symbols/signs, while exteriorizing, inscribing and incorporating it into a material element, which would materialize a "memory" or "past experiences", making them visually accessible (d'Errico et al. 2017; De Smedt \& De Cruz 2011; Osborne 2004; Valera 2007). (Fig. 8)

This is also the case and the technique visible in the "Talas", that were used in the North of Portugal, during the XX century (Alves 1910; Dias \& Dias 1981; Kuchenbuch 2006). This "talas" are usually sticks with one-meter length, with incision done by a razor, regularly spread through the available surface. Each space corresponds to a house in the village to which the tala is referent, being organised according to the position each house has in the community. This visual representation of a circular reality - village - in a linear surface creates a new prearranged order, that is used as a record and followed in every administrative procedure, from voting, access to animals and even fees, each subject with an independent tala (Alves 1910; Dias \& Dias 1981; 
Kuchenbuch 2006). Also, the groove's size, depth and position were codified in a "writing" system that would be known by every resident of the village, including signs (deeper and broader incisions) to represent rivers (Kuchenbuch 2006).

During the end of the $3^{\text {rd }}$ millennium BC, and in the SW of the Peninsula, the involved groups would not only communicate numerical references but indeed also cycles, another type of symbolic information or even landscape elements that could be related to social or even agricultural practices. This communication would be expressed in many ways, from the decoration of ceramic containers and ideotechnique elements, to the way the structures were built and even in their clothes and body's ornaments. However, and as seen in Portuguese talas, the engravings of the understudy dagger also present variations in shape, depth, width and angle, which decreases the possibility of this dagger corresponding to a saw. As such, and considering that this communicative and mnemonic technique is a plausible hypothesis, it is questionable if the codes would be wholly known and transmitted (through culture) by the entire community/communities or only by some elements (Valera 2007), mainly due to the "exclusive" character of the "dagger" (atypical typology) and (so far) scarcity of elements that can be connected to this communication method.

Another element that can hypothetically be understood as a second transformation is related to the physical state in which it was recovered, since it was deformed.

On the one hand, this may reflect an intentional act of bending the "dagger" that disabled it by physically signalling the end of its "life", preventing its reuse. The typological divergence could have been understood as a differentiating element that might have had some agency or value, either symbolic, economic, social or other, inscribed in it. As such, its "deactivation" can also be assumed as a social display, once the deformation can increase the value and symbolism of this metallic element - acting as a visual imprint while maintaining its symbolic integrity (Jârlea 2008). This can be seen, for example, during the European Bronze Age, with fragmented artefacts being included into hoards (Târlea 2008; Vilaça 2006), and even during the peninsular chalcolithic, not only with the intentional deposition of vessels that are only half preserved (Valera 2019), but of other artefacts as well, such as lunulae (Valera 2010).

Also, the act of deforming the artefact can be associated with the last filling moment of Ditch 7 , possibly working as a closure deposition, in line with what is suggested for the contemporary monument of Chãs do Carvalhal. In this site, a Bell Beaker funerary monument, a deposition of Palmela points/arrowheads and daggers was carried out in the tumulus (da Cruz 1992).

On the other hand, it is necessary to consider and evaluate the existence of post-depositional processes that might have interfered with the original shape of the blade. This type of disturbance is particularly worrisome in Perdigões's upper contexts, once this site was deeply ploughed in the late '90s (Lago et al. 1998). Ditch 7's initial deposits were also affected by this quite significant event in the archaeological site's biography, being startling stroked by one of the ploughing marks, whose trajectory is tangent to the location of the "dagger" (Valera 2015b). The deposition of the artefact is thus vulnerable to the impact caused by the ploughing, once it certainly remobilised some of the stones that fill the top of the second recutting moment of Ditch 7, which could have pressed the metallic object, causing the deformation with which it was recovered. So, the intentionality or accidental circumstance of the bending are both viable hypotheses. 
The isolated deposition and the absence of associated materials also raise questions concerning the existence of a possibly bigger metallic deposit and the intentionality behind the deposition. In a Chalcolithic chronology, the metallic artefacts are rarely deposited in an isolated way, corresponding to the antecedents of what will later be known as the Bronze Age "hoards" (Târlea 2008; Vilaça 2006), as it can be observed in the contemporaneous monument 1 of Chãs do Carvalhal, in Serra da Aboboreira (da Cruz 1992). The presence of isolated artefacts starts to be more recurrent during the course of Bronze Age (Vilaça 2006), emphasizing that also in single depositions there is a deliberated choice in placing an artefact, that might have served as an evocative element to memories, on the ground (Târlea 2008). (Fig. 9)

This panorama creates a dichotomy between the Chalcolithic collective artefactual behaviour and the tendency to the individualisation present in several spheres of the Bronze Age, highlighting and materializing a shifting process in the social ideology from the end of the $3^{\text {rd }}$ millennium $B C$, from which the "dagger" recovered in Ditch 7 might be one of the first material exemplars.

However, and considering the merge between the later re-cutting of Ditch 7, the stone filling and the deposition, it is possible to think the intentionality behind both the deposition and the physical deformation of this object as an integrant part, with a particular and inaccessible agency, of the deposition process - as detected in similar structures in Perdigões (Basilio and Cabaço, 2019). To this hypothesis also contributes the scarcity of metallic artefacts that are deposited in ditches, not being known any regional parallels for this type of practice.

\section{Final remarks}

The metallic element recovered on top of Ditch 7 of Perdigões showed to be particularly challenging not only due to its atypical typology and inherent terminology, but also to its biography and depositional context.

Firstly, it must be highlighted that the trajectory and interpretation of the metallic artefact are directly connected to Ditch 7, more specifically with the later recutting moment of this structure, dated from the last quarter of the 3rd millennium BC. However, it is also related, and dependent, of the interpretations that have been made of Perdigões, being this metallic element "active" in a disrupting and shifting moment on the trajectory of the enclosure (Valera \& Basílio 2017).

This chronology might justify the atypical shape of the understudy artefact, hampering one of the most immediate archaeological analysis - the classification. Its elongated shape, flattened tang and serrated edge prevented direct parallels with contemporaneous counterparts, namely the Palmela and Jabalina points/arrowheads, and the daggers. However, and considering the variability observed in all the categories, the element recovered in Perdigões resembles both the tangs of Palmela point/arrowhead and the blades of daggers, being assumed as a hybrid element that is in "transition" between these two morphologies. Still, this "mutation" is not observable in what concerns the composition of this "dagger", produced by $98,9 \%$ of copper. It bears a resemblance to assemblages that have a Chalcolithic tradition, contradicting the general tendency drawn by the analysed regional contexts, in which the arsenical copper seems to gain presence in artefacts that are classifiable as "weapons" (Valério et al. 2017; 2016a). As such, this metallic element presents characteristics that link it with the Chalcolithic practices, but at the same time divergent traces that might be related to the transformations that were being felt in 
the last decades of the 3rd millennium BC in SW Iberia (Valera 2015a; In press; Valera \& Basílio 2017).

Secondly, the deposition and the biography of this element are also noteworthy, with several moments of usage and reconversion of the artefact, to which possibly other social usages can be ascribed.

The serrated edge can represent a new functionality - possibly as a saw - and an extension on the life of the artefact as a tool. However it can also reflect the integration of this "strange" blade into ongoing social practices, acting as a mnemonic mechanism by materializing either memories, cycles, events, gatherings or even orders (d'Errico et al. 2017; De Smedt \& De Cruz 2011). Adding to that, the signs and codes applied in this device in the form of incisions could be shared between the agents of a group/region or could be used as a differentiating element.

Also, the physical state of the blade, that was recovered bent in half can be indicative of intentional acts of deformation, in order to mark the amortisation of the artefact and possibly even of the Ditch 7. This process would work as a social display, that regardless of the meaning and usage of this metallic element, might have increased its value and even its symbolism (Jârlea 2008). Nevertheless, this distortion of the blade can also be inherent to the place and situation in which it was deposited - isolated as an integrant part of the filling of the second recutting of Ditch 7, alongside uncountable stone elements - since this area was remobilised due to a deep ploughing.

In sum, the metallic element deposited on top of Ditch 7 of Perdigões combines and materialises distinct influences - technologies and traditions that can be ascribed to the Chalcolithic and variations that can be related to the shifting environment felt at the end of the $3^{\text {rd }}$ millennium $B C$ in SW Iberia. However, further chemical analyses are required, in order to fully characterise the metallurgical signature of Perdigões. Nonetheless, the artefact from ditch 7 made it possible to suggest different interpretations and ascribe distinct meanings to an element that remains, so far, unique not only in Perdigões, but also in Iberia.

\section{Acknowledges}

This paper was developed in the Global Program of Investigation of Perdigões (INARP) directed by NIA-Era Arqueologia.SA and in the project PRDC/EPH-ARO/0798/2017, funded by Fundação para a Ciência e Tecnologia.

\section{References}

ALVES, F.M. (1910): Vestígios do regimen agrário comunal. (Ilustração Transmontana 3): 137142.

ANDRADE, M.A. (2016): "Intervenções de Manuel de Mattos Silva no Megalitismo da área de Avis". Revista Portuguesa de Arqueologia 1: 19-23.

APPADURAI, A. (1986): The social life of things: Commodities in cultural perspective. Cambridge University Press.

ATANCE, C.M., O'NEILL, D.K. (2001): "Episodic future thinking". Trends in cognitive sciences 5: 533-539.

BASÍLIO, A.C., CABAÇO, N. (2019): "An end that perpetuates: a cairn from the end of the 3rd millennium BC at Perdigões." In: Valera, A.C. (Ed.): Fragmentation and Depositions in Pre 
and Proto-Historic Portugal. Lisboa: Núcleo de investigação arqueológica (NIA) / Era Arqueologia S.A.: 105-124.

BASÍLIO, A.C. (2018): Dinâmicas ocupacionais na segunda metade do $3^{\circ}$ milénio a.C. nos Perdigões: Continuidades e descontinuidade. (Master's Thesis). Universidade do Algarve, Faro.

BLANCO-GONZÁLEZ, A., LILLIOS, K.T., LÓPEZ-SÁEZ, J.A., DRAKE, B.L. (2018): "Cultural, Demographic and Environmental Dynamics of the Copper and Early Bronze Age in Iberia (3300-1500 BC): Towards an Interregional Multiproxy Comparison at the Time of the 4.2 ky BP Event." Journal of World Prehistory 31: 1-79. https://doi.org/10.1007/s10963-0189113-3

BLASCO, C., RIOS, P., LIESAU, C. (eds.) (2011): Yacimientos calcolíticos con campaniforme de la región de Madrid: nuevos estudios. Universidad Autónoma de Madrid.

BOTTAINI, C.E., BRUNETTI, A., MONTERO-RUIZ, I., VALERA, A., CANDEIAS, A., MIRÃO, J. (2018): "Use of Monte Carlo simulation as a tool for the nondestructive energy dispersive X-ray fluorescence (ED-XRF) spectroscopy analysis of archaeological copper-based artifacts from the Chalcolithic site of Perdigões, Southern Portugal". Applied spectroscopy 72:1727.

CARO, J.L., COMPAÑA, J.M., RODRÍGUEZ VINCEIRO, F., SANTAMARÍA, J.A. (2015): "Primeros vestigios de metalurgia en el foso 1 (Puerta 1) del yacimiento de Perdigões. Un avance arqueométrico (Reguengos de Monsaraz, Portugal)". Proceedings of the VII Encuentro de Arqueología del suroeste peninsular (Aroche-Serpa, 2013). Aroche: 279-298.

COMENDADOR REY, B. (1998): "Los inicios de la metalurgia en el Noroeste de la Península Ibérica". Brigantium: Boletín do Museu Arqueolóxico e Histórico da Coruña.

D'ERRICO, F., DOYON, L., COLAGÉ, I., QUEFFELEC, A., LE VRAUX, E., GIACOBINI, G., VANDERMEERSCH, B., MAUREILLE, B. (2017): "From number sense to number symbols. An archaeological perspective". Philosophical Transactions of the Royal Society B: Biological Sciences 373. https://doi.org/10.1098/rstb.2016.0518

DA CRUZ, D. DE J. (1992): A Mamoa 1 de Chã de Carvalhal no contexto arqueológico da Serra da Aboboreira. Coimbra: Faculdade de Letras da Universidade de Coimbra/ Instituto de Arqueologia.

DE SMEDT, J., DE CRUZ, H. (2011): "The role of material culture in human time representation: Calendrical systems as extensions of mental time travel". Adaptive Behavior 19: 63-76. https://doi.org/10.1177/1059712310396382

DIAS, J., DIAS, M. (1981): Rio de Onor: comunitarismo agro-pastoril. Editorial Presença.

EVANGELISTA, L.S., VALERA, A.C. (2019): "Segmenting and depositing: the manipulation of the Human body in Ditched Enclosures seen from Perdigões". In: Valera, A.C. (Ed.): Fragmentation and Depositions in Pre and Proto-Historic Portugal. Núcleo de investigação arqueológica (NIA) / Era Arqueologia S.A. Lisboa: 47-69.

KAISER, J.M. (2003): "Puntas de flecha de la Edad del Bronce en la Península Ibérica. Producción, circulación y cronología Bronze Age arrow-heads of the Iberian Peninsula". Complutum $14,73-106$.

KUCHENBUCH, L. (2006): Les baguettes de taille au Moyen Âge: un moyen de calcul sans écriture. Ecrire, compter, mesurer. Vers une histoire des rationalités pratiques: 113-142.

LAGO, M., DUARTE, C., VALERA, A., ALBERGARIA, J., ALMEIDA, F. (1998): "Povoado dos Perdigões (Reguengos de Monsaraz): dados preliminares dos trabalhos arqueológicos realizados em 1997". Revista Portuguesa de Arqueologia 1: 45-152.

ORESTES VIDIGAL, R., VALÉRIO, P., ARAÚJO, M.F., SOARES, A.M.M., MATALOTO, R. (2016): "MicroEDXRF study of Chalcolithic copper-based artefacts from Southern Portugal: MicroEDXRF study of Chalcolithic copper-based artefacts (Portugal)". X-Ray Spectrometry 45: 63-68. https://doi.org/10.1002/xrs.2658

OSBORNE, R. (2004): "Hoards, votives, offerings: the archaeology of the dedicated object". World Archaeology 36: 1-10. https://doi.org/10.1080/0043824042000192696 
SHANKS, M., TILLEY, C.Y. (1987): Social theory and archaeology. Polity Press Cambridge.

SOARES, A.M., ALVES, L.C., FRADE, J.C., VALÉRIO, P., ARAÚJO, M. DE F., CANDEIAS, A., SILVA, R.J.C., VALERA, A.C. (2014): "Bell Beaker Gold Foils from Perdigões (Southern Portugal)Manufacture and Use". Proceedings of the 39th International Symposium for Archaeometry. Leuven: 120-24.

SOARES, J. (2011): Transformações sociais durante o III milénio BC no sul de Portugal: o povoado do Porto das Carretas. (Memórias d'Odiana, $2^{\text {a }}$ Série).

JÂRLEA, A. (2008): "The Concept of 'Selective Deposition". Peuce (Serie Nouă) - Studii şi cercetari de istorie şi arheologie VI: 63-132.

TULVING, E. (2002): "Episodic memory: from mind to brain". Annual review of psychology 53: 125.

VALERA, A.C. (2019): "Segmentation and depositional practices in Prehistoric South Portugal: Between ontological stability and fluidity". In: Valera, A.C. (Ed.): Fragmentation and Depositions in Pre and Proto-Historic Portugal. Núcleo de investigação arqueológica (NIA) / Era Arqueologia S.A., Lisboa: 9-29.

VALERA, A.C. (ed.) (2018): "Os Perdigões Neoliticos: Génese e desenvolvimento (de meados do 4o aos inícios do 3o milénio a.C. Núcleo de investigação arqueológica (NIA) / Era Arqueologia S.A., Lisboa.

VALERA, A.C. (2015a): "Social change in the late 3rd millennium BC in Portugal: The twilight of enclosures". In: Meller, H., Risch, R., Jung, R., Arz, H.W. (Eds.): 2200 BC - Ein Klimasturz Als Ursache Für Den Zerfall Der Alten Welt? 2200 BC - A Climatic Breakdown as a Cause for the Collapse of the Old World. Presented at the 7th Archaeological Conference of Central Germany October 23-26, 2013, Halle (Saale): 409-427.

VALERA, A.C. (2015b): Relatório dos trabalhos de escavação de 2015 no Recintos dos Perdigões. Direcção Geral do Património Cultural, Lisboa.

VALERA, A.C. (2014): "Continuidades e descontinuidades entre $03^{\circ}$ e a primeira metade do $2^{\circ}$ milénio ane no Sul de Portugal: alguns apontamentos em tempos de acelerada mudança". A Idade do Bronze em Portugal: Os dados e os problemas: 298-316.

VALERA, A.C. (2013): Relatório dos trabalhos de escavação de 2013 no Recintos dos Perdigões. Direcção Geral do Património Cultural, Lisboa.

VALERA, A.C. (2010): "Marfim no recinto calcolítico dos Perdigões (1):"Lúnulas", fragmentação e ontologia dos artefactos". Apontamentos de Arqueologia e Património 5: 31-42.

VALERA, A.C. (2008): "Mapeando o Cosmos: uma abordagem cognitiva aos recintos da PréHistória Recente". Era-Arqueologia: 112-127.

VALERA, A.C. (2007): Dinâmicas locais de identidade: estruturação de um espaço de tradição no 3 milénio AC (Fornos de Algodres, Guarda). Município de Fornos de Algodres.

VALERA, A.C. (In press): "Morte no Expresso do Ocidente: razões para um colapso social no final do $3^{\circ}$ milénio a.C. no Sudoeste da Península Ibérica". In: Lopes, S.S., Gomes, S. (Eds.): Seminário Internacional Entre o $3^{\circ}$ e o $2^{\circ}$ milénio AC: Que tipo de viragem? - Pré-Atas.

VALERA, A.C., BASÍLIO, A.C. (2017): "Approaching Bell Beakers at Perdigões enclosures (South Portugal): site, local and regional scales". In: Gonçalves, V. dos S. (Ed.): Sinos e Taças: Junto Ao Oceano e Mais Longe: Aspectos Da Presença Campaniforme Na Península Ibérica. Lisboa: estudos \& memórias 10: 82-97.

VALERA, A.C., EVANGELISTA, L.S. (2014): "Anthropomorphic Figurines at Perdigões Enclosure: Naturalism, Body Proportion and Canonical Posture as Forms of Ideological Language". European Journal of Archaeology 17: 286-300. https://doi.org/10.1179/1461957114Y.0000000057

VALERA, A.C., GODINHO, R. (2010): "Ossos humanos provenientes dos fossos 3 e 4 e gestão da morte nos Perdigões". Apontamentos de Arqueologia e Património 6: 29-39.

VALERA, A.C., GODINHO, R. (2009): "A gestão da Morte nos Perdigões (Reguengos de Monsaraz): Novos dados, Novos Problemas". Estudos Arqueológicos de Oeiras: 371-387. 
VALERA, A.C., SILVA, A.M., CUNHA, C., EVANGELISTA, L.S. (2014a): "Funerary practices and body manipulation at Neolithic and Chalcolithic Perdigões ditched enclosures (south Portugal)". In Valera, A.C. (ed.): Recent Prehistoric Enclosures and Funerary Practices in Europe: $37-57$.

VALERA, A.C., SILVA, A.M., MÁRQUEZ ROMERO, J.E. (2014b): "The temporality of Perdigões enclosures: absolute chronology of the structures and social practices". SPAL-Revista de Prehistoria y Arqueología: 11-26.

VALÉRIO, P., SOARES, A.M.M., ARAÚJO, M.F. (2016a): "An overview of chalcolithic copper metallurgy from southern Portugal". Menga: Revista de prehistoria de Andalucía: 31-50.

VALÉRIO, P., SOARES, A.M.M., ARAÚJO, M.F., SILVA, R.J.C., BAPTISTA, L. (2016b): "Middle bronze age arsenical copper alloys in southern Portugal". Archaeometry 58: 1003-1023.

VALÉRIO, P., SOARES, J., ARAÚJO, M.F., ALVES, L.C., TAVARES DA SILVA, C. (2019): "The Composition of the São Brás Copper Hoard in Relation to the Bell Beaker Metallurgy in the South-western Iberian Peninsula". Archaeometry 61: 392-405. https://doi.org/10.1111/arcm.12422

VALÉRIO, P., VIDIGAL, R.O., ARAÚJO, M.F., SOARES, A.M.M., SILVA, R.J.C., MATALOTO, R. (2017): "Manufacture of copper weapons and tools from the chalcolithic settlement of São Pedro (Portugal)". Materials and Manufacturing Processes 32: 775-780. https://doi.org/10.1080/10426914.2016.1198030

VIGNAUX, G. (2000): O Demónio da Classificação: Pensar/ organizar, Instituto Piaget. ed, Epigénese, Desenvolvimento e Psicologia.

VILAÇA, R. (2006): "Depósitos de bronze do território português. Um debate em aberto". O Arqueólogo Português, série IV 24: 9-150. 


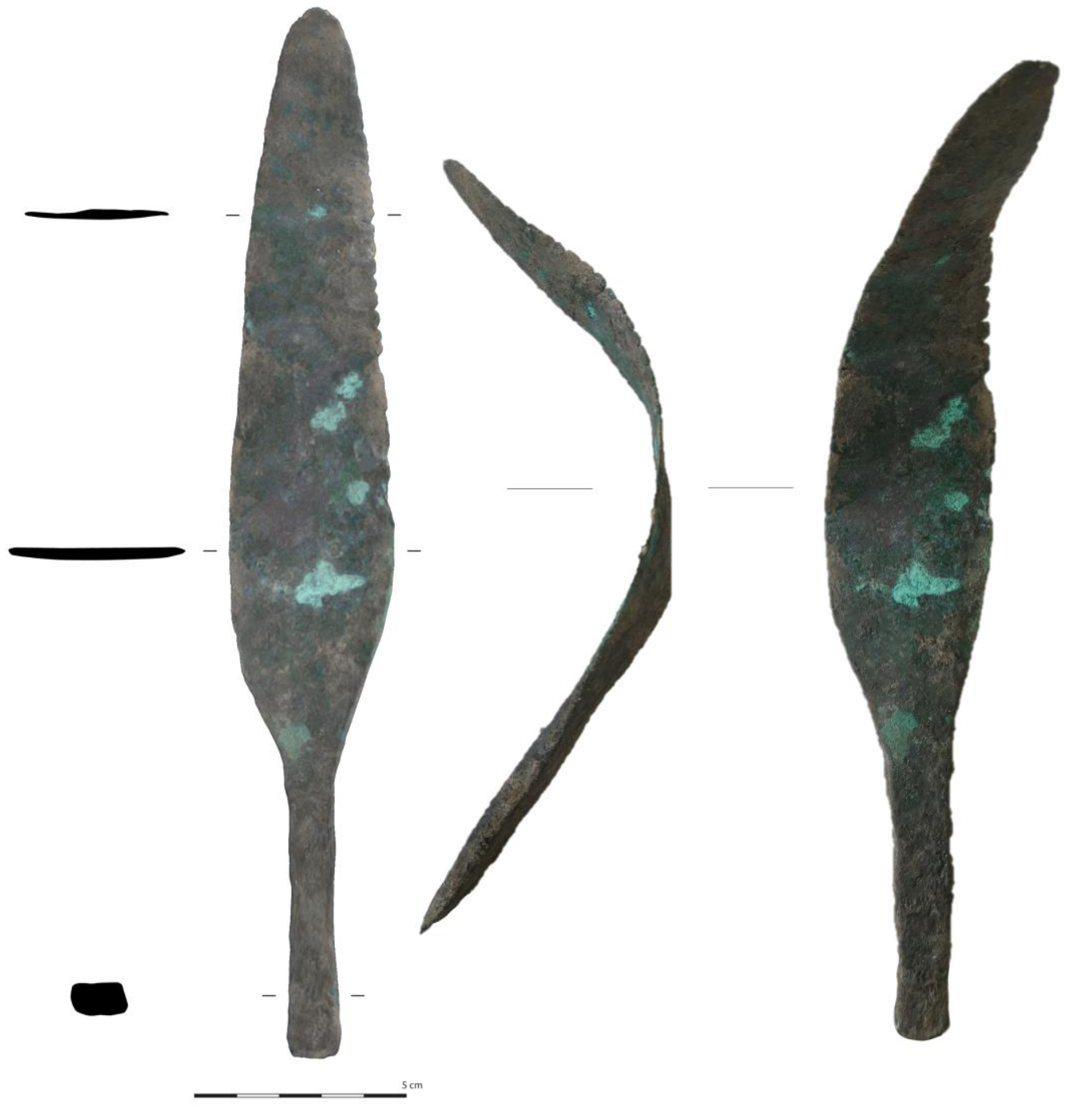

Fig. 1 - Metallic artefact from Ditch 7 of Perdigões reconstructed and in its original shape. 


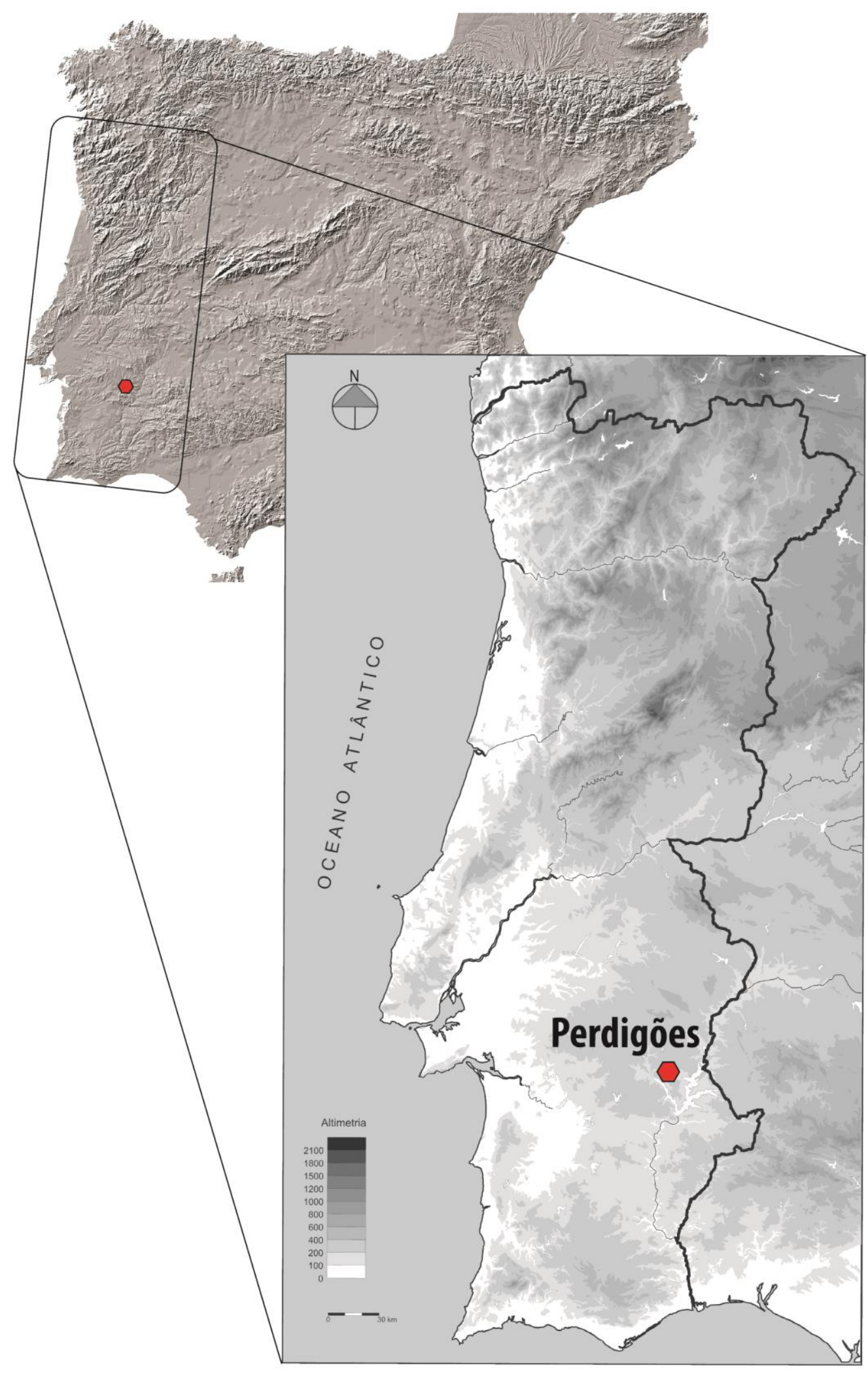

Fig. 2 - Implantation of Perdigões in Iberia and in Portugal. 


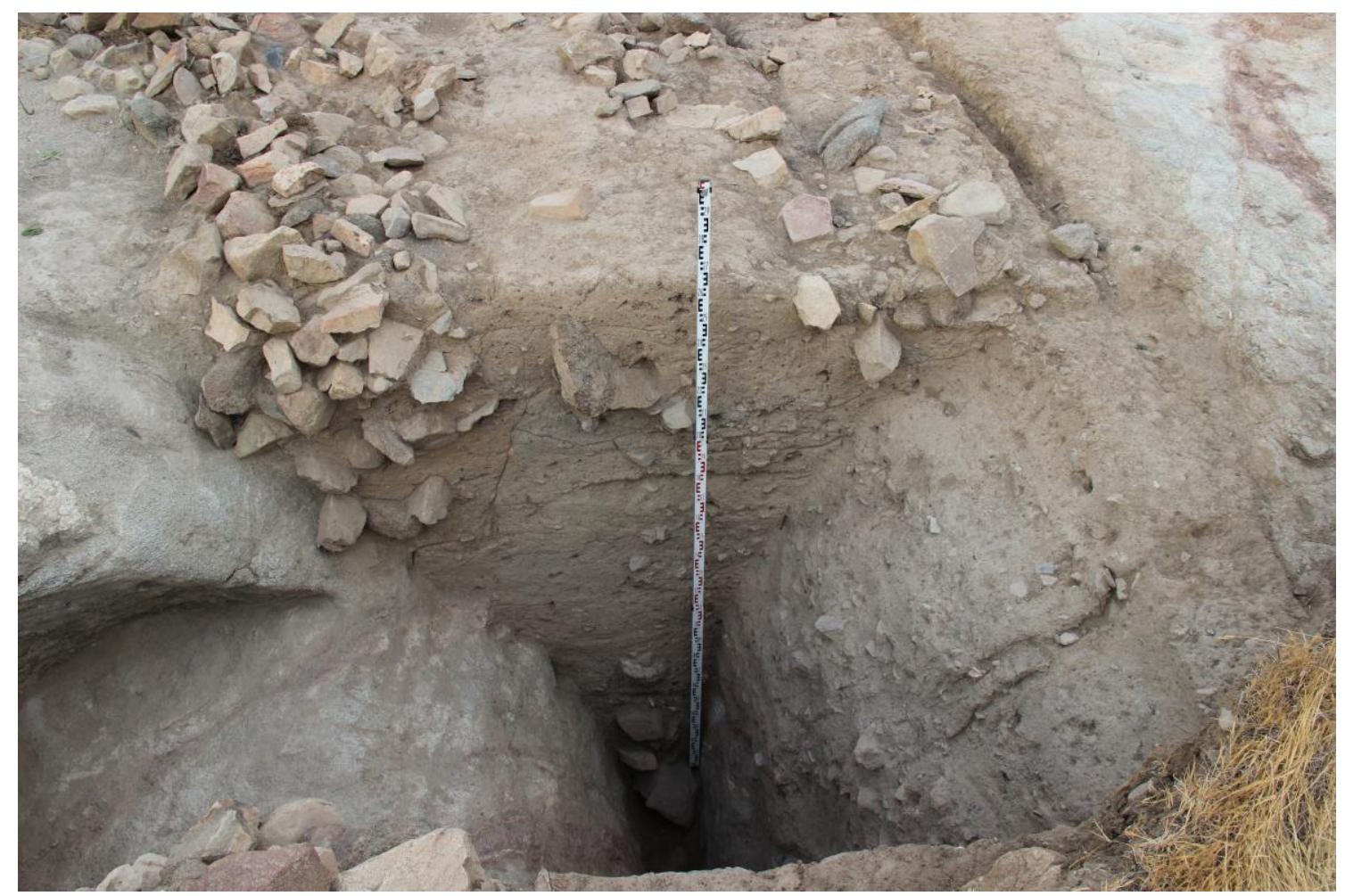

Fig. 3 - Ditch 7 of Perdigões Complex of Enclosures.

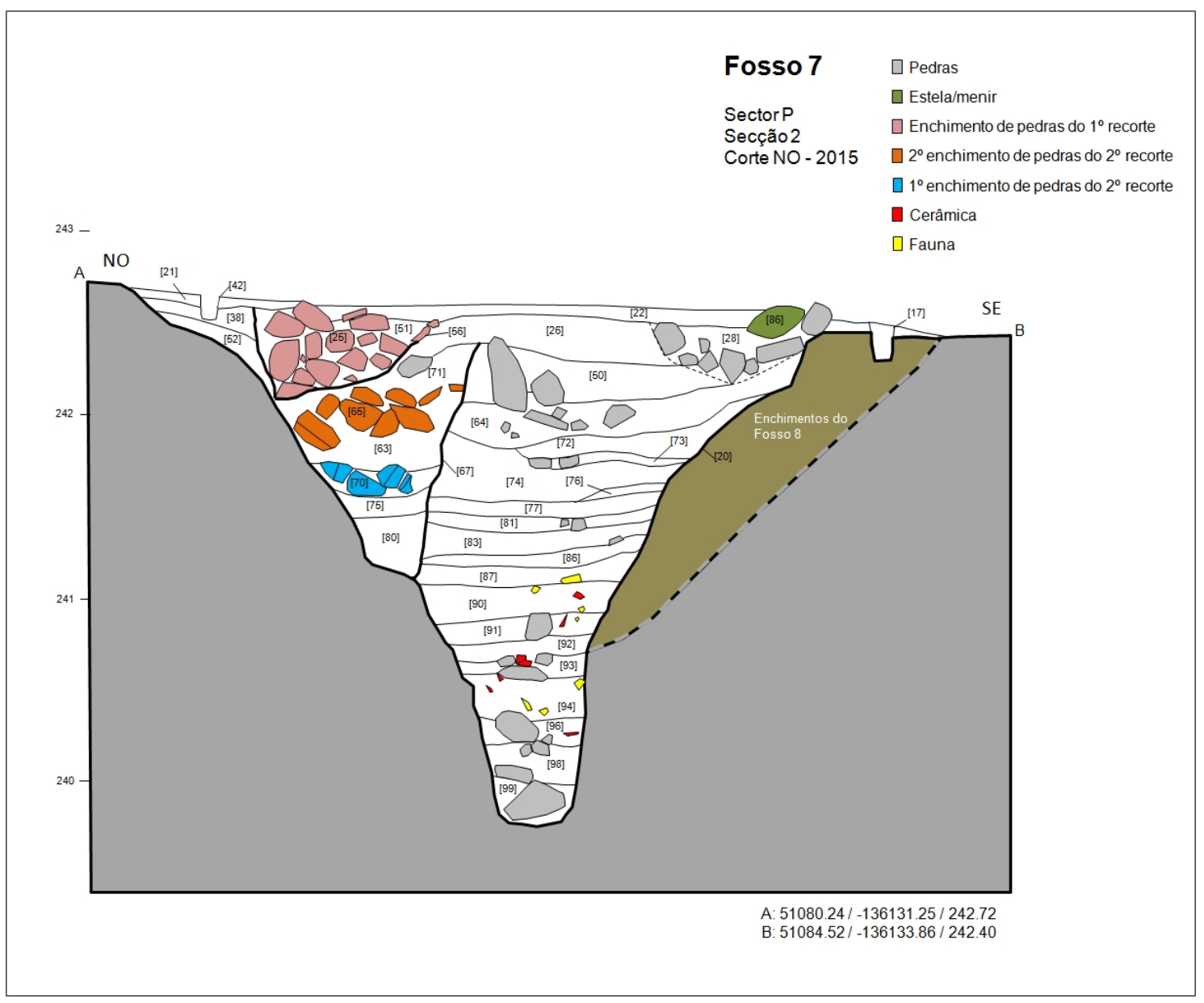

Fig. 4 - Final north section of Ditch 7. 

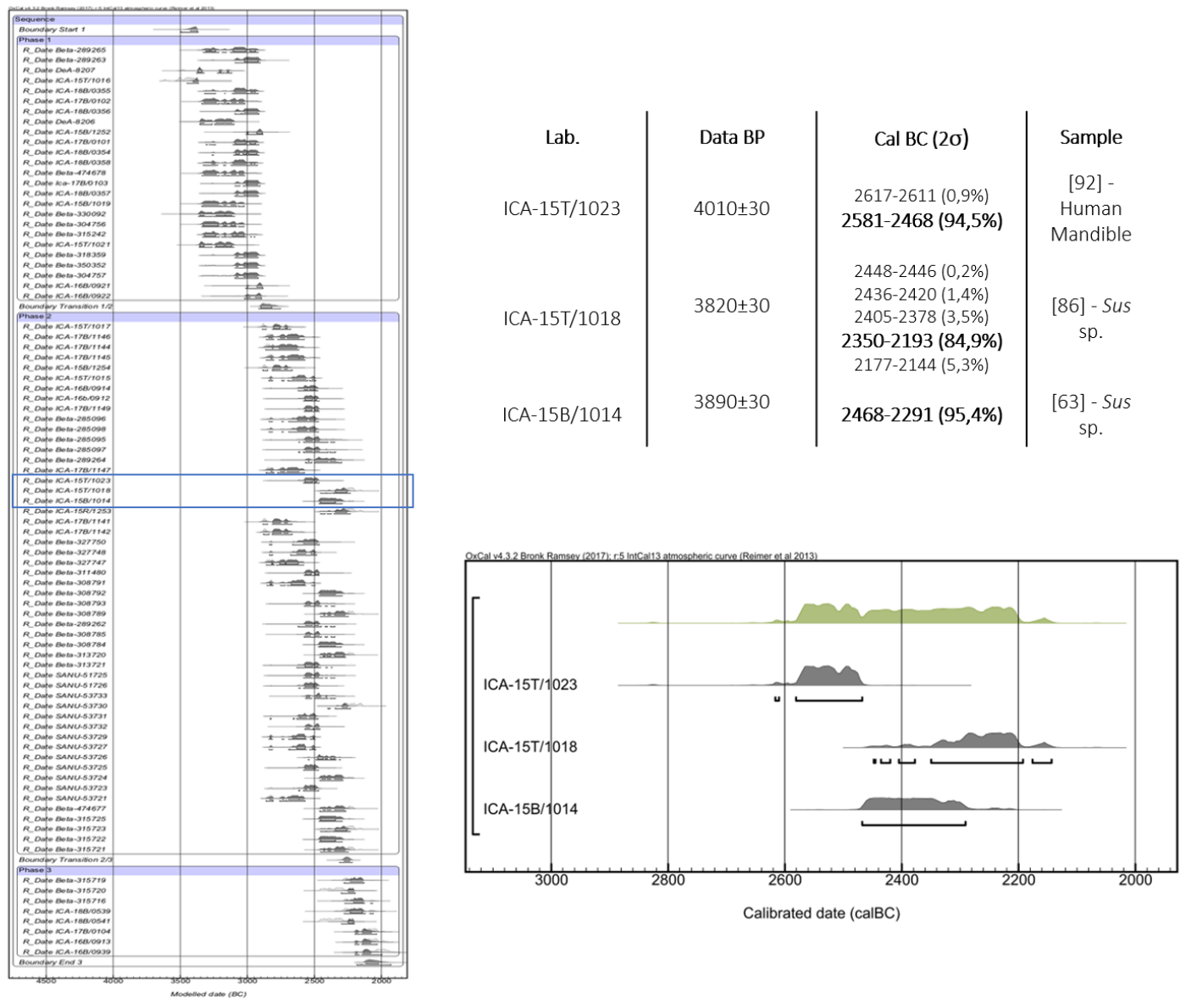

Fig. 5 - Sum and radiocarbon dates from Ditch 7 and its relationship with the available chronological information for Perdigões 


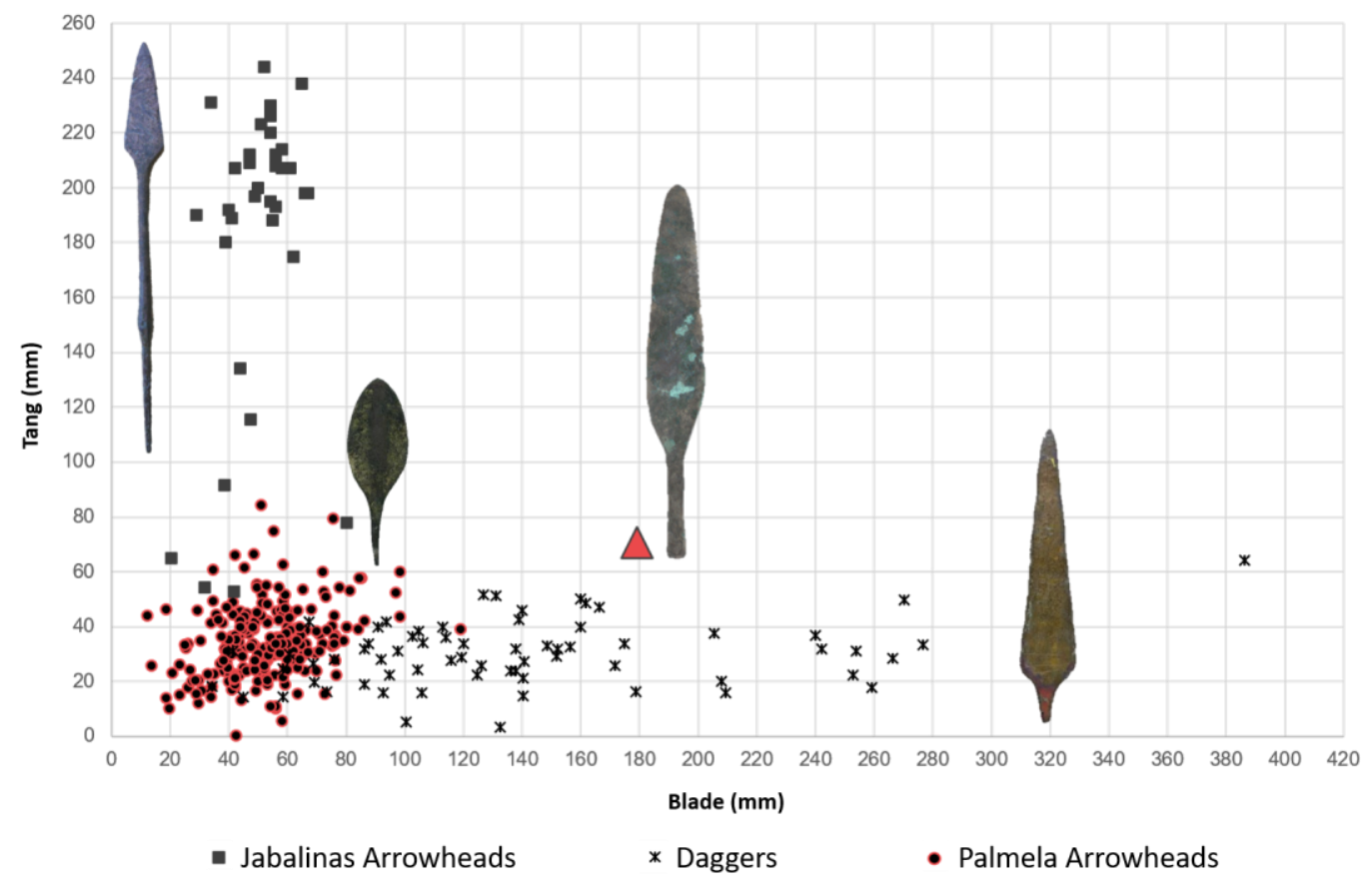

Fig. 6 - Corelation between the dimension of the tangs and blades (in mm) of the contemporaneous Palmela, Javalina points and daggers. 


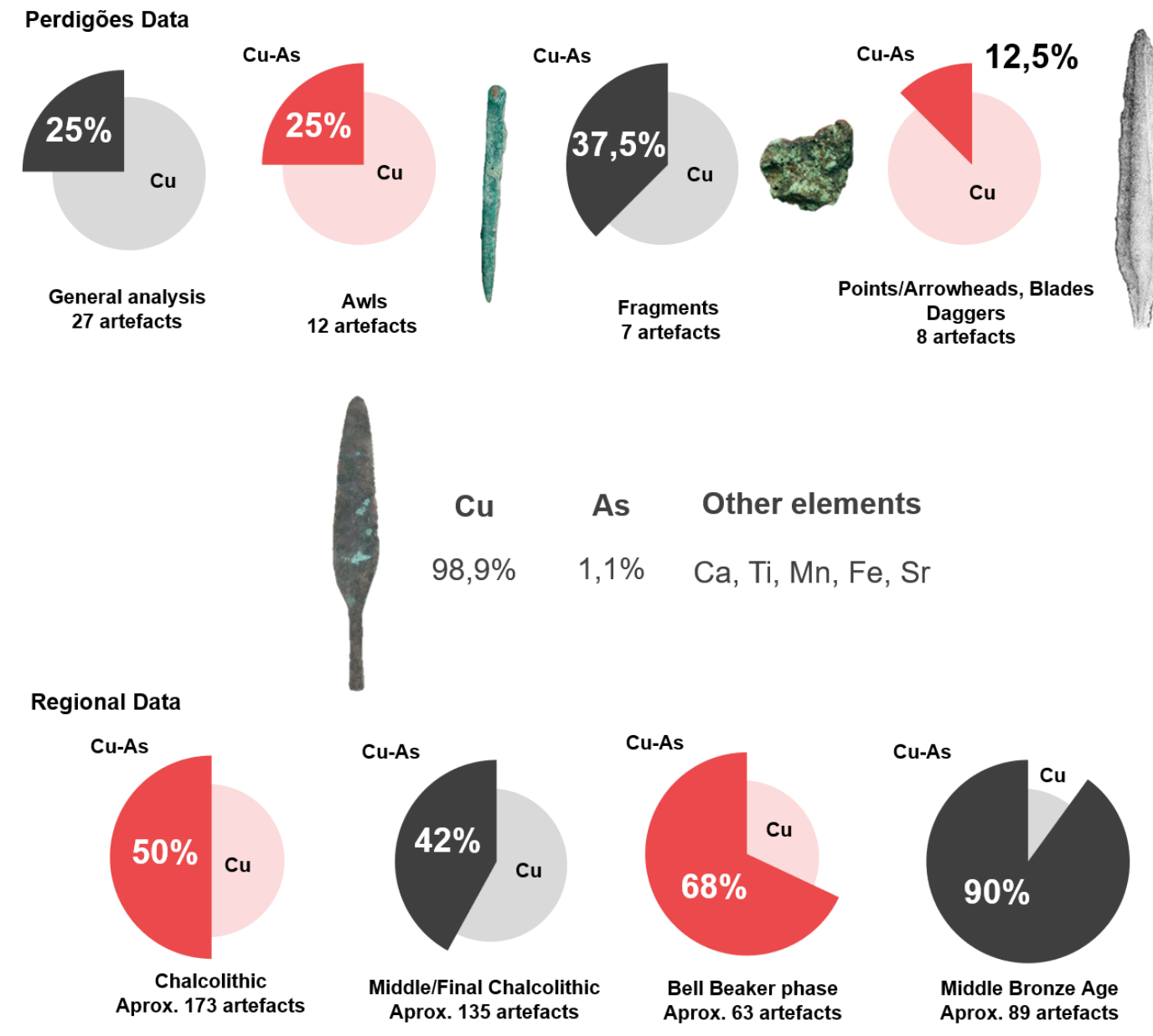

Fig. 7 - General composition of the analysed metallic elements from Perdigões (Bottaini et al. 2018) and comparison with the panorama drawn by the regional data (according to Valério et al. 2017). 


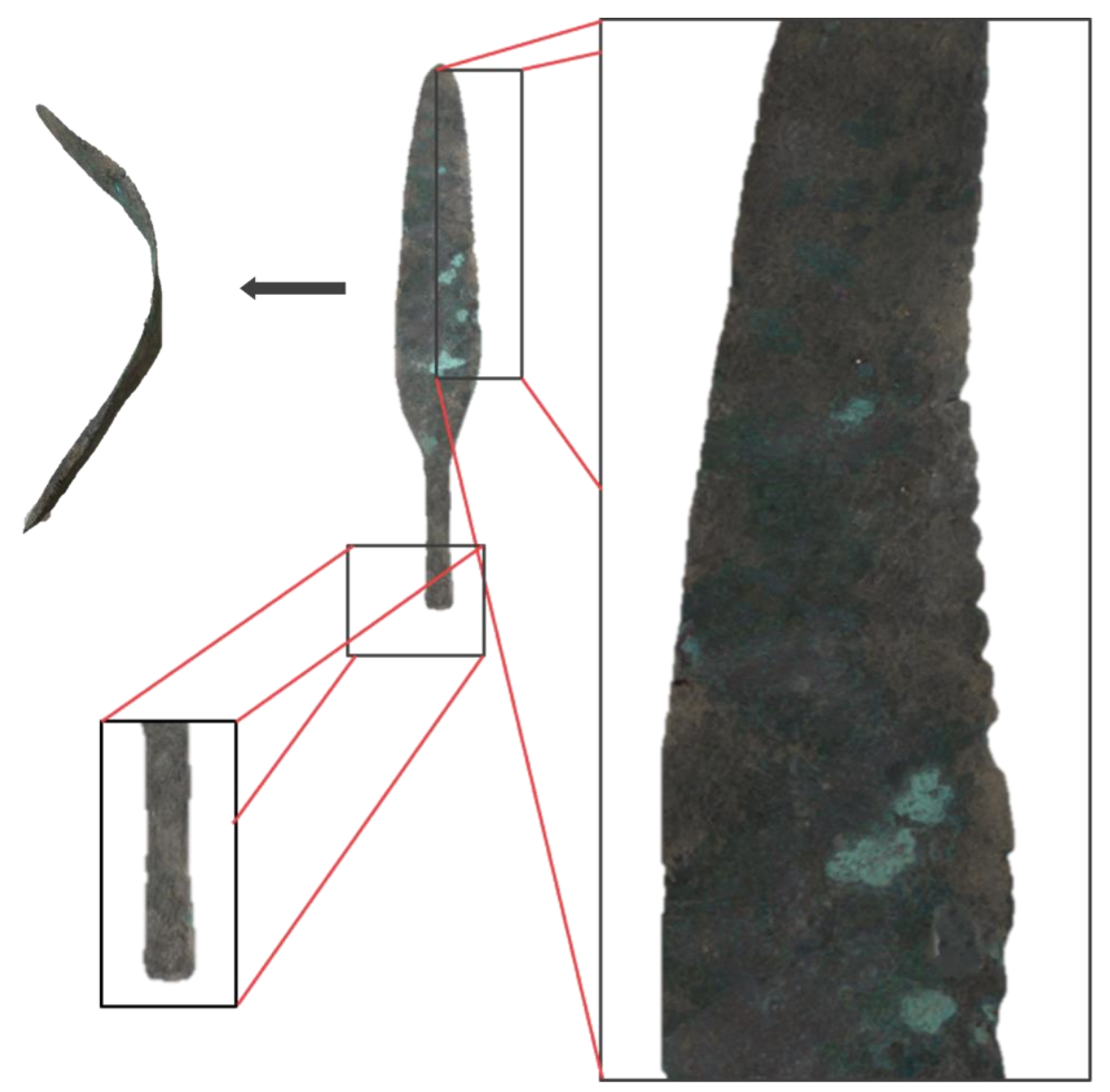

a.
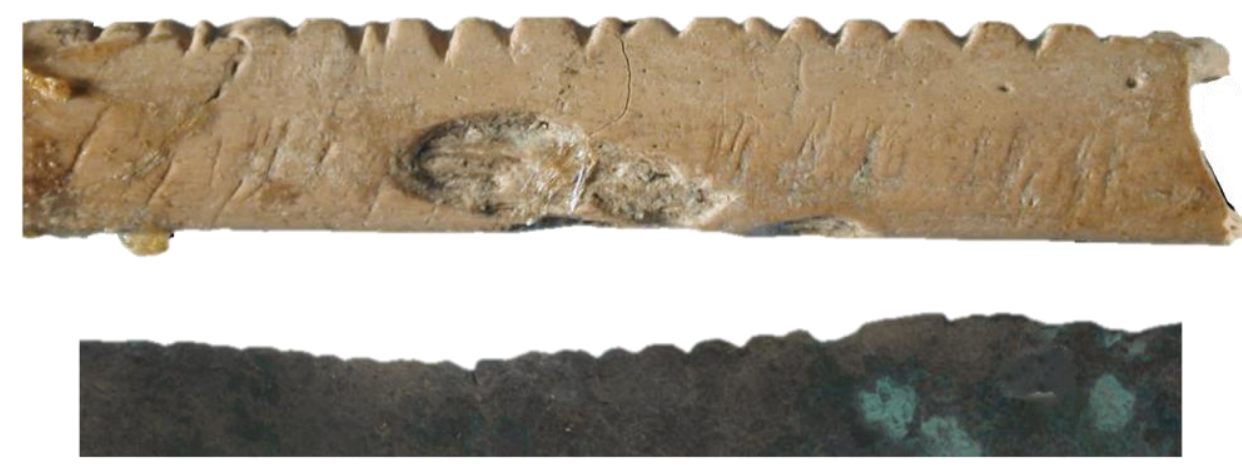

b.

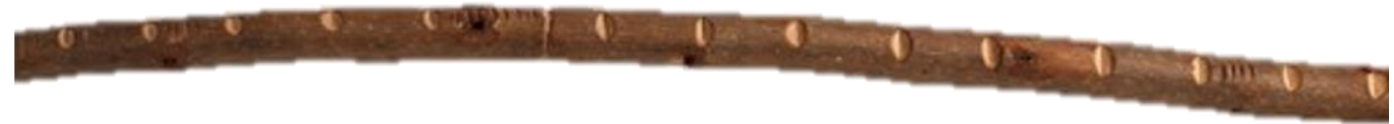

Fig. 8 - The several modifications that the blade from Ditch 7 went through. Comparison between the edge of the understudy artefact, the Palaeolithic Border Cave layer 1BS Lower B-C (a. - d'Errico et al. 2017) and the Portuguese Talas (b.) 


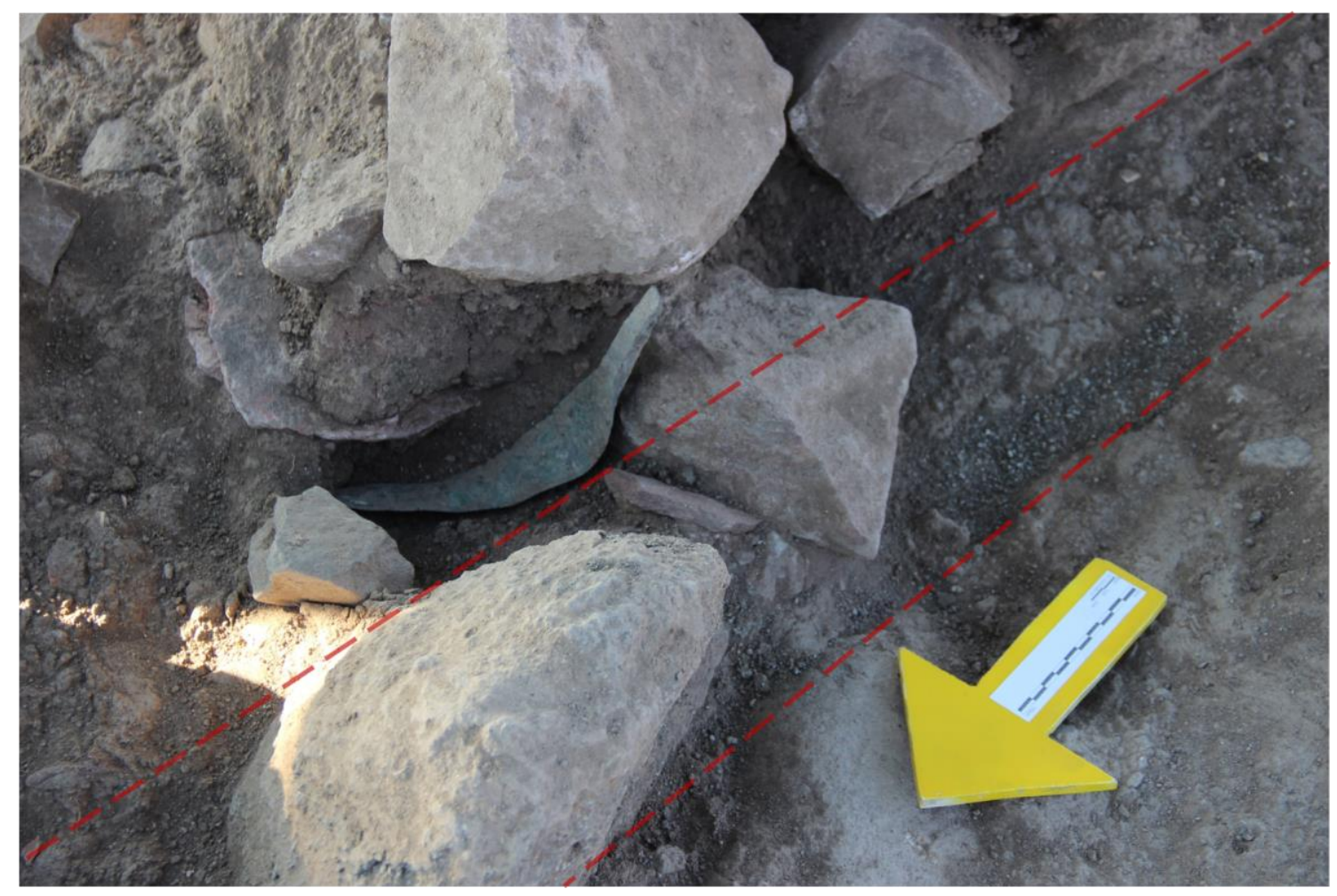

Fig. 9 - Original deposition of the metallic artefact, within the stone elements from the last recutting moment of Ditch 7. The trajectory of a ploughing mark is highlighted in red. 